\section{Nitrogen Fertility Influences Growth and Susceptibility of Rhododendrons to Phytophthora ramorum}

\author{
Rita L. Hummel ${ }^{1}$, Marianne Elliott, Gary Chastagner, Robert E. Riley, \\ Kathy Riley, and Annie DeBauw \\ Washington State University, Puyallup Research and Extension Center, 2606 \\ W. Pioneer, Puyallup, WA 98371
}

Additional index words. foliar disease, Rhododendron 'Cunningham's White', Rhododendron 'English Roseum', Rhododendron 'Compact P.J.M.', nursery production, ammonium nitrate

\begin{abstract}
Growth and susceptibility of evergreen Rhododendron 'English Roseum', 'Cunningham's White', and 'Compact P.J.M.' to Phytophthora ramorum in response to biweekly nitrogen $(N)$ fertilizer application at rates of 25,75 , and $150 \mathrm{mg} N$ per 11.4- $\mathrm{L}$ container was evaluated during two growing seasons. At the end of both growing seasons, horticultural evaluation of the different plants showed that $150 \mathrm{mg} N$-fertilized cultivars had superior shoot growth, visual quality, leaf color, and the highest leaf $N$ concentration, whereas the 25-mg $\mathbf{N}$ cultivars were inferior for these characteristics. Plants fertilized with the 75-mg $\mathrm{N}$ rate were typically intermediate to the 150 - and $25-\mathrm{mg} \mathrm{N}$ plants for the measured characteristics. During the first growing season, the number of flower buds on 'Cunningham's White' and 'English Roseum' was not influenced by $N$ rate but the second season bud numbers increased with increasing $\mathbf{N}$ fertilizer. Foliar susceptibility to $P$. ramorum was influenced by $\mathbf{N}$ fertilizer application rates in the most susceptible cultivars, 'English Roseum' and 'Cunningham's White', in which lesion size and infection frequency both increased at higher $\mathrm{N}$ rates. The results were variable in 'Compact P.J.M.', the most resistant cultivar.
\end{abstract}

The environmental impact of container nursery production practices has come under increasing scrutiny in recent years (Majsztrik et al., 2011). Fertilizer applications to containerized plants typically exceed requirements and irrigation is often excessive, resulting in nutrient leaching, runoff, and potential contamination of surface and groundwaters (Biernbaum, 1992; Chen et al., 2001; Lea-Cox et al., 2004; Majsztrik et al., 2011). Research has shown that marketable containerized plants can be produced using lower $\mathrm{N}$ rates and less water (Cabrera, 2003; $\mathrm{Ku}$ and Hershey, 1997; Majsztrik et al., 2011; Ristvey et al., 2007; Scagel et al., 2011). The Best Management Practices (BMP) Guide (Yeager et al., 2007) describes fertilization and irrigation strategies nurseries can follow to prevent environmental contamination.

In addition to reducing the potential for $\mathrm{N}$ pollution, lower $\mathrm{N}$ applications may reduce the incidence of plant disease. Under some conditions, high $\mathrm{N}$ rates have been reported

Received for publication 29 Nov. 2012. Accepted for publication 19 Mar. 2013.

This research was supported in part by the Washington State University College of Agricultural, Human, and Natural Resource Sciences' Emerging Research Issues for Washington Agriculture Grant Program.

Mention of a trademark, proprietary product, or vendor does not constitute a guarantee or warranty nor does it imply approval to the exclusion of other products or vendors that also may be suitable.

${ }^{1}$ To whom reprint requests should be addressed; e-mail hummelrl@wsu.edu. to increase disease levels in plant disease pathosystems (Halsall et al., 1983; Mittelstrab et al., 2006). The exotic oomycete plant pathogen Phytophthora ramorum, the causal agent of sudden oak death, has caused significant damage to forests in coastal northern California and millions of dollars in losses in the nursery industry in California, Oregon, and Washington (Dart and Chastagner, 2007b; Hansen et al., 2005a, 2005b; Werres et al., 2001). Many Phytophthora species cause root diseases on their hosts; however, P. ramorum can colonize the roots of hosts such as rhododendron without causing symptoms (Vercauteren et al., 2013). Phytophthora ramorum causes symptoms on the aerial portions of its hosts. On many ornamental and forest plants, $P$. ramorum only causes leaf spots or shoot dieback in contrast to the lethal stem cankers found on oak (Quercus spp.), tanoak (Notholithocarpus densiflorus), and beech (Fagus spp.).

In 2000 to 2002, scientists demonstrated that the spread of $P$. ramorum was associated with the movement of nursery stock, and control efforts were established by the U.S. Department of Agriculture Animal Plant Health Inspection Service (APHIS). These efforts focused on surveying nurseries and eradicating the pathogen (APHIS, 2010; Dart and Chastagner, 2007a). However, the repeated recovery of $P$. ramorum from production and retail nursery sites suggests nurseries can potentially act as reservoirs for the pathogen (Dart and Chastagner, 2007b; Tjosvold et al., 2002). Thus, regulators, researchers, and industry have come to the realization that an integrated approach will be essential to effectively and sustainably limit the spread of $P$. ramorum by nursery stock (Dart and Chastagner, 2007b).

There are currently no data available to support or refute how $\mathrm{N}$ fertility affects disease severity of $P$. ramorum on nursery hosts. Phytophthora ramorum is the model organism of choice because it is a driving force behind current BMP reforms. Rhododendron is the most logical model plant to use in pathological studies of $P$. ramorum because Rhododendron spp. account for most of the plants associated with positive nursery finds in North America (APHIS, 2012; Dart and Chastagner, 2007a). Rhododendron species and hybrids are also important hosts of $P$. ramorum in Europe (De Dobbelaere et al., 2009; Werres et al., 2001).

In this study, we use the $P$. ramorumrhododendron pathosystem as a model to investigate the dynamics between $\mathrm{N}$ application rates and disease development. Specifically, we tested the hypothesis that higher $\mathrm{N}$ fertility would result in increased disease incidence and severity.

\section{Materials and Methods}

Plant material. Three rhododendron cultivars shown to vary in their susceptibility to $P$. ramorum (M. Elliott, unpublished data; Tooley et al., 2004), 'English Roseum' (highly susceptible), 'Cunningham's White' (moderately susceptible), and 'Compact P.J.M.' (moderately resistant), were purchased from a wholesale nursery as 2-yearold \#1 (2.8-L, $15 \mathrm{~cm}$ diameter $\times 21 \mathrm{~cm}$ tall) container-grown plants. On 3 Apr. 2008, they were transplanted to \#3 (11.4-L, $25.5 \mathrm{~cm}$ diameter $\times 22.5 \mathrm{~cm}$ tall) containers in a $100 \%$ douglas-fir bark substrate amended with Scotts Micromax micronutrient mix at a rate of $1038 \mathrm{~g} \cdot \mathrm{m}^{-3}$. Plants were randomized on a gravel nursery bed and irrigated daily with overhead sprinkler irrigation but were not fertilized to allow for depletion of residual fertilizer in the substrate. After 8 weeks, just before the start of $\mathrm{N}$ treatments, all plants were moved to a drip irrigation system. Water was applied through an emitter consisting of a $56-\mathrm{cm}$ length of $3.2-\mathrm{mm}$ microtubing with holes laser drilled in a preset spacing of $9 \mathrm{~cm}$ that was formed into an $18-\mathrm{cm}$ diameter circle around the stem of each plant. The circular emitter was attached through a tee-fitting to a non-perforated $3.2-\mathrm{mm}$ microtube that was attached to a pressure-compensating drip emitter originating on the $12.7-\mathrm{mm}$ irrigation main line. This arrangement allowed for uniform distribution of water to the surface of the growth substrate. Water was applied daily at $0800 \mathrm{HR}$ until plant growth and increasing temperatures necessitated twice-daily applications at 0800 and 1400 HR. Containers were watered to minimize leaching, leaching fraction (volume of leachate/volume of water applied) not to exceed 0.1 , by monitoring leachate volumes and adjusting irrigation as needed. 
Nitrogen treatments. On 2 June 2008, after plants were attached to the drip system, fertilizer treatments started. Fertilizer solutions were surface-applied twice a week at three $\mathrm{N}$ rates: 100,300 , or $600 \mathrm{mg} \cdot \mathrm{L}^{-1} \mathrm{~N}$. Phosphorus $(\mathrm{P})$ and potassium $(\mathrm{K})$ were applied at a uniform rate of $100 \mathrm{mg} \cdot \mathrm{L}^{-1} \mathrm{P}$ and $200 \mathrm{mg} \cdot \mathrm{L}^{-1} \mathrm{~K}$ to all plants at each $\mathrm{N}$ application. Thus, all plants received the same amount of $\mathrm{P}$ and $\mathrm{K}$; only the $\mathrm{N}$ rate varied. The fertilizer solutions were prepared using combinations of ammonium nitrate (EM Science, Germany), potassium sulfate (J.T. Baker Chemical Co., NJ), and potassium phosphate monobasic (EM Science). The water used to mix the fertilizer solutions had a $\mathrm{pH}$ of 6.8 and an electrical conductivity of $0.2 \mathrm{dS} \cdot \mathrm{m}^{-1}$. The volume of solution applied at each fertilization was $250 \mathrm{~mL}$ resulting in an $\mathrm{N}$ application rate equivalent to 25,75 , or $150 \mathrm{mg} \mathrm{N} /$ container.

The experiment consisted of a factorial combination of three cultivars by three $\mathrm{N}$ rates in a randomized complete block design with eight individual plant replications. Plants were grown on a gravel nursery bed in full sun.

In mid-Oct. 2008, all plants were moved to a fiberglass overwintering structure. In late Mar. 2009, all plants were returned to the nursery bed drip irrigation system and, starting on 2 Apr. 2009, provided with the same fertilizer treatments as applied in 2008.

Plant growth and quality measurements. Initial plant height and the narrowest and widest canopy widths were recorded before the start of $\mathrm{N}$ treatments. In early October of 2008 and 2009, plant height and the widest and narrowest canopy width were measured again and the yearly increase in height and widths was determined. From these data, yearly plant growth increases were calculated as the incremental shoot growth index (ISGI) using the following formula ISGI $=[$ (widest width increase + narrowest width increase) $/ 2+$ height increase]/2 (Krucker et al., 2010). Plant visual quality was rated on a 1 to 5 scale where $5=$ superior quality; $4=$ high quality; 3 = marketable quality; 2 = low quality; and $1=$ poor-quality plant. Leaf color and the number of visible flower buds on 'English Roseum' and 'Cunningham's White' were also recorded. Color of the interveinal lamina of two mature leaves per plant from the most recent growth flush was determined quantitatively with a Minolta CR200b Chroma Meter (Minolta, Ramsay, NJ). The CIELAB coordinates, $\mathrm{L}^{*} \mathrm{a}^{*} \mathrm{~b}^{*}$, were recorded, and the chroma $\left(\mathrm{C}^{*}\right)$ and hue angle $\left(\mathrm{h}^{\circ}\right)$ were calculated (McGuire, 1992). An average L*, C*, and $\mathrm{h}^{\circ}$ for each plant was determined from the two leaves sampled. L* measures the lightness or value of the color from black (0) to white $(100) . C^{*}$ is a measure of color saturation or intensity and indicates the intensity of color from gray ( 0 ) toward a pure chromatic color. Saturation increases with the number. $\mathrm{Hue}^{\circ}$ is the attribute of color perceived (red, yellow, green, blue, or intermediate between adjacent pairs arranged on a $360^{\circ}$ color wheel). Leaf color and flower bud numbers of 'Compact P.J.M.' were not measured as a result of fall color development and difficulty discerning vegetative from floral buds on this cultivar.

Root growth was measured by removing plant root balls from the containers and rating root length from 1 to 4 where 1 = roots grew halfway to the container bottom; 2 = roots grew three-fourths of the way to the container bottom; 3 = roots to container bottom; and $4=$ roots circling container bottom. Root density in the periphery of the root ball was also rated from 1 to 4 where $1=$ no roots visible at the root ball periphery; $2=$ few roots visible; $3=$ many roots visible but growing medium still obvious; and $4=$ solid root mass with little or no growing medium visible.

Leaf nitrogen concentration. Leaf tissue for $\mathrm{N}$ and carbon $(\mathrm{C})$ analysis was collected in early October of 2008 and 2009 by harvesting four fully mature, current-season leaves from each plant. The leaves of two plants within a cultivar and treatment were combined to produce four replicates, which were dried at $65^{\circ} \mathrm{C}$ to constant weight, ground, and sent to the University of Nebraska analytical laboratory for analysis of total $\mathrm{N}$ and total $\mathrm{C}$. Total $\mathrm{N}$ and $\mathrm{C}$ were determined using a combustion analyzer equipped with an infrared detector (LECO Instruments, St. Joseph, MI)

Susceptibility to P. ramorum. Six currentseason leaves were collected from each plant in early October of 2008 and 2009. Leaves that were fully expanded and hardened off were selected. Phytopthora ramorum inoculum was prepared from cultures of an NA1 lineage isolate (03-74-N10A-A from Rhododendron $\times$ 'Unique', A2 mating type) grown for 4 weeks on one-third V8 agar $(66 \mathrm{~mL}$ of clarified V8 concentrate $(100 \mathrm{~mL} \mathrm{V8} \mathrm{juice,}$ $1.43 \mathrm{~g} \mathrm{CaCO}_{3}$ centrifuged $15 \mathrm{~min}$ at $5000 \mathrm{rpm}$, $15 \mathrm{~g}$ Difco Bacto agar, $950 \mathrm{~mL} \mathrm{H}_{2} \mathrm{O}$ ). The NA1 lineage was the most commonly isolated clonal lineage of $P$. ramorum in both forest and nursery environments at the time of the experiment.

A zoospore suspension was prepared by flooding plates with $6 \mathrm{~mL}$ sterile deionized water and refrigerating for $2 \mathrm{~h}$ and then left at room temperature for $1 \mathrm{~h}$. The spore concentration was determined with a hemacytometer and ranged from $5 \times 10^{5}$ to $1 \times 10^{6}$ zoospores $/ \mathrm{mL}$ for the tests. A $10-\mu \mathrm{L}$ drop of zoospore suspension was pipetted onto the lower leaf surface. The leaf tissue beneath

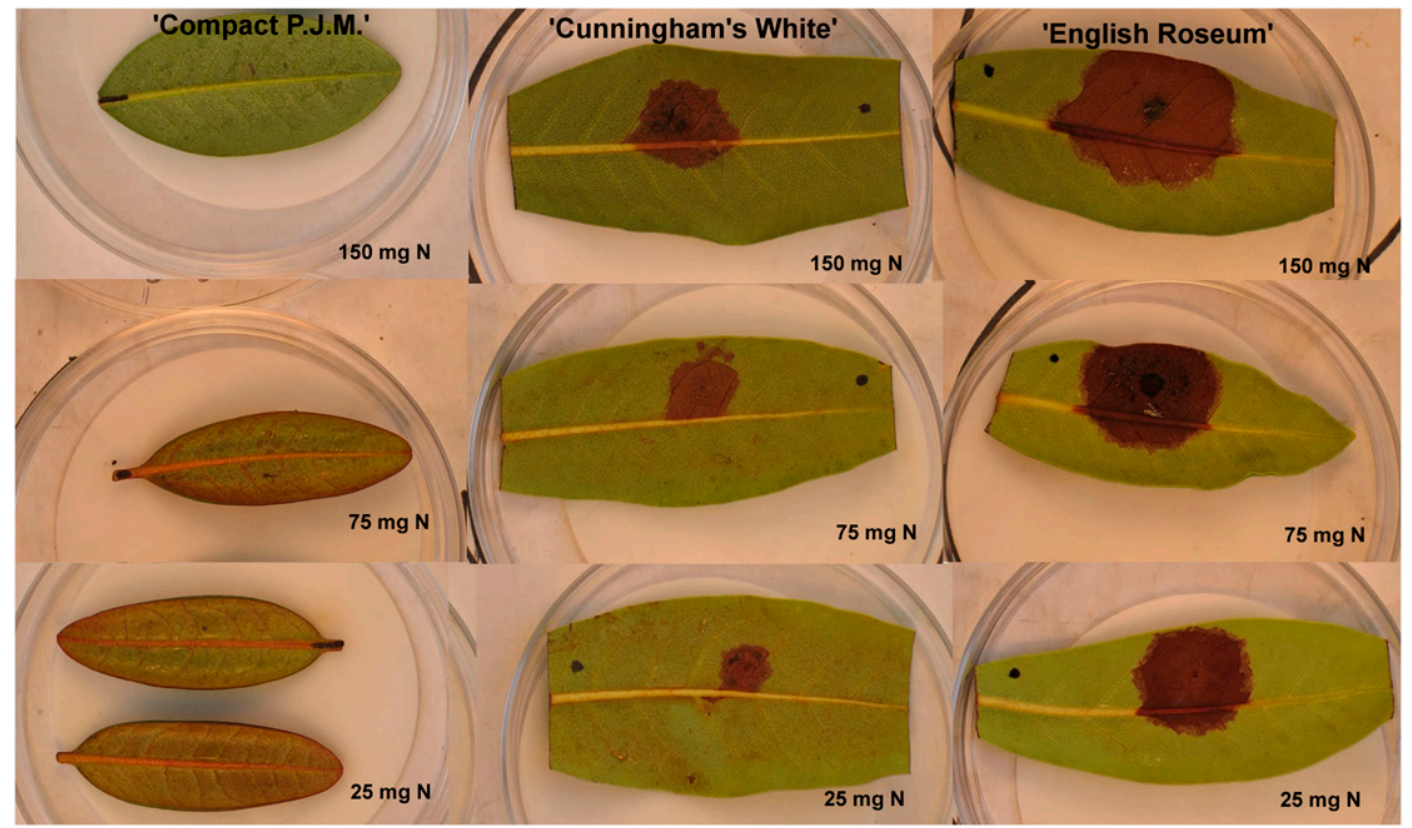

Fig. 1. Detached rhododendron leaves inoculated with Phytophthora ramorum after $10 \mathrm{~d}$ of incubation. Representative leaves for each nitrogen (N) treatment and cultivar are shown. A pinprick wound was created in each leaf after inoculation with a zoospore suspension of P. ramorum. 
drops on three leaves was wounded using an insect pin, whereas the tissue beneath each drop on the other three leaves was left unwounded. Leaves were incubated on moist filter paper in petri plates in the dark at 19 to $20{ }^{\circ} \mathrm{C}$ for $10 \mathrm{~d}$ (Tooley et al., 2004). In a preliminary experiment, a set of wounded leaves of each cultivar was inoculated with a $10-\mu \mathrm{L}$ drop of sterile distilled water and no lesions were formed (data not shown). Digital photographs of each leaf were taken and lesion size was determined using the program ASSESS (ASSESS V. 2.0; APS Press, St. Paul, MN). Only infections producing visible symptoms were considered in this study, although isolation of $P$. ramorum from inoculated leaves of some species suggests that asymptomatic infection is possible (Frankel, 2008; Riedel et al., 2012). Infection frequency was determined based on presence or absence of a visible lesion (Fig. 1).

Data analysis. Plant growth, quality, leaf $\mathrm{N}$ concentration, color, and $\mathrm{C}: \mathrm{N}$ ratio data were subjected to two-way analysis of variance (ANOVA; PROC GLM; SAS 9.1, SAS Institute Inc., Cary, NC) using cultivar and N treatment as the main effects. However, significant two-factor interactions necessitated the use of one-way ANOVA to test N-rate significance. Mean separations were done with a protected Tukey's Studentized range test.

Disease incidence and severity data were analyzed using R Version 2.14.0 (R Development Core Team 2011). A $\chi^{2}$ test was performed to examine differences in infection frequency (percent leaves infected) between $\mathrm{N}$ treatments for all cultivars and between cultivars for all $\mathrm{N}$ treatments followed by the Marascuilo multiple comparison test for proportions (Zwick and Marascuilo, 1984). The Shapiro-Wilk test for normality was performed on lesion area measurements for each wounding treatment and measurement time. Non-parametric tests were used when non-normality was found in the data. Differences in lesion area between wounded and unwounded treatments for all cultivars and $\mathrm{N}$ concentrations were evaluated using the Wilcoxon signed-rank test for paired samples. Differences in lesion area between $\mathrm{N}$ treatments and cultivars were examined separately using the Kruskal-Wallis test followed by Dunn's multiple comparison test. The relationship among foliar $\mathrm{N}$ concentration, foliar $\mathrm{C}: \mathrm{N}$ ratio, and lesion area for each cultivar was assessed with linear regression using pooled mean values of lesion area on wounded and unwounded leaves for each cultivar/ $\mathrm{N}$ rate combination.

\section{Results}

Cultivar response to nitrogen rate. Shoot growth response to $\mathrm{N}$ rate at the end of one growing season (2008) was similar for 'Cunningham's White' and 'English Roseum' with plants fertilized at the high $\mathrm{N}$ rate, $150 \mathrm{mg} \mathrm{N} /$ container, making more growth than plants at the medium, $75 \mathrm{mg} \mathrm{N} /$ container, and low, $25 \mathrm{mg} \mathrm{N} /$ container, $\mathrm{N}$ rates (Table 1).
Although these cultivars had smaller ISGI at the $25-\mathrm{mg} \mathrm{N}$ rate, the difference between the $75-$ and $25-\mathrm{mg} \mathrm{N}$ rates was not significant. At the 150-mg N rate, 'Compact P.J.M.' had a greater ISGI than at the $25-\mathrm{mg} \mathrm{N}$ rate but growth of plants fertilized at the $75-\mathrm{mg} \mathrm{N}$ rate did not differ significantly from either 150 - or 25-mg N plants (Table 1).

Plant visual quality was similar at the 150 and 75-mg $\mathrm{N}$ rates for 'Compact P.J.M.' and 'Cunningham's White' after one growing season (Table 1), whereas 'English Roseum' quality improved with increasing $\mathrm{N}$ rate. Quality of all three cultivars was lower at the 25-mg N rate. The number of flower buds set on 'Cunningham's White' and English Roseum' the first growing season was not influenced by $\mathrm{N}$ rate (Table 2 ).

After two growing seasons (2009), ISGI of both 'Cunningham's White' and 'English Roseum' indicated plants grew larger as the $\mathrm{N}$ fertilizer rate increased (Table 1). ISGI of 'Compact P.J.M.' was larger at the 150- and $75-\mathrm{mg} \mathrm{N}$ rates and smaller at the $25-\mathrm{mg} \mathrm{N}$ rate. Cultivar quality ratings at the end of two growing seasons followed the ISGI pattern with quality of 'Cunningham's White' and 'English Roseum' increasing with N rate,

Table 1. Effect of nitrogen rates on first (2008) and second (2009) growing season incremental shoot growth index (ISGI), shoot quality, nitrogen concentration and $\mathrm{C}: \mathrm{N}$ ratio in Rhododendron 'Compact P.J.M.', 'Cunningham's White', and 'English Roseum' leaves. ${ }^{\mathrm{z}}$

\begin{tabular}{|c|c|c|c|c|c|c|c|c|}
\hline \multirow{3}{*}{$\begin{array}{l}\text { Nitrogen rate } \\
\text { (mg N/container) }\end{array}$} & \multicolumn{5}{|c|}{ Percent } & \multicolumn{3}{|c|}{ Percent } \\
\hline & $\begin{array}{c}\mathrm{ISGI}^{\mathrm{y}} \\
(\mathrm{cm})\end{array}$ & $\begin{array}{c}\text { Shoot } \\
\text { quality }^{\mathrm{x}}\end{array}$ & $\begin{array}{c}\text { leaf } \\
\text { nitrogen }\end{array}$ & Leaf $C: N$ & $\begin{array}{l}\text { ISGI } \\
(\mathrm{cm}) \\
\end{array}$ & $\begin{array}{c}\text { Shoot } \\
\text { quality }\end{array}$ & $\begin{array}{c}\text { leaf } \\
\text { nitrogen }\end{array}$ & $\begin{array}{l}\text { Leaf } \\
\mathrm{C}: \mathrm{N} \\
\end{array}$ \\
\hline & \multicolumn{4}{|c|}{2008 growing season } & \multicolumn{4}{|c|}{2009 growing season } \\
\hline & \multicolumn{8}{|c|}{ Compact P.J.M. } \\
\hline 150 & $14.1 \mathrm{a}^{\mathrm{w}}$ & $3.8 \mathrm{a}$ & $1.63 \mathrm{a}$ & $32 \mathrm{a}$ & $16.9 \mathrm{a}$ & $4.3 \mathrm{a}$ & $1.30 \mathrm{a}$ & $40 \mathrm{a}$ \\
\hline 75 & $12.1 \mathrm{ab}$ & $3.3 \mathrm{a}$ & $1.44 \mathrm{~b}$ & $36 \mathrm{a}$ & $18.4 \mathrm{a}$ & $3.9 \mathrm{a}$ & $1.08 \mathrm{~b}$ & $48 \mathrm{~b}$ \\
\hline \multirow[t]{2}{*}{25} & $6.5 \mathrm{~b}$ & $2.5 \mathrm{~b}$ & $1.24 \mathrm{c}$ & $41 \mathrm{~b}$ & $11.7 \mathrm{~b}$ & $2.9 \mathrm{~b}$ & $0.95 \mathrm{~b}$ & $53 \mathrm{~b}$ \\
\hline & \multicolumn{8}{|c|}{ Cunningham's White } \\
\hline 150 & $7.3 \mathrm{a}$ & $4.4 \mathrm{a}$ & $1.64 \mathrm{a}$ & $31 \mathrm{a}$ & $13.6 \mathrm{a}$ & $4.8 \mathrm{a}$ & $1.05 \mathrm{a}$ & $46 \mathrm{a}$ \\
\hline 75 & $5.0 \mathrm{~b}$ & $4.5 \mathrm{a}$ & $1.17 \mathrm{~b}$ & $43 \mathrm{~b}$ & $10.5 \mathrm{~b}$ & $4.3 \mathrm{~b}$ & $0.85 \mathrm{~b}$ & $57 \mathrm{~b}$ \\
\hline \multirow[t]{2}{*}{25} & $4.4 \mathrm{~b}$ & $3.0 \mathrm{~b}$ & $0.72 \mathrm{c}$ & $68 \mathrm{c}$ & $3.9 \mathrm{c}$ & $3.0 \mathrm{c}$ & $0.78 \mathrm{~b}$ & $62 \mathrm{~b}$ \\
\hline & \multicolumn{8}{|c|}{ English Roseum } \\
\hline 150 & $11.2 \mathrm{a}$ & $4.6 \mathrm{a}$ & $1.25 \mathrm{a}$ & $40 \mathrm{a}$ & $19.3 \mathrm{a}$ & $4.8 \mathrm{a}$ & $0.95 \mathrm{a}$ & $52 \mathrm{a}$ \\
\hline 75 & $7.1 \mathrm{~b}$ & $3.8 \mathrm{~b}$ & $1.03 \mathrm{~b}$ & $49 \mathrm{~b}$ & $13.5 \mathrm{~b}$ & $3.9 \mathrm{~b}$ & $0.83 \mathrm{~b}$ & $59 \mathrm{ab}$ \\
\hline 25 & $4.5 \mathrm{~b}$ & $2.6 \mathrm{c}$ & $0.76 \mathrm{c}$ & $66 \mathrm{c}$ & $4.4 \mathrm{c}$ & $2.6 \mathrm{c}$ & $0.75 \mathrm{~b}$ & $65 \mathrm{~b}$ \\
\hline
\end{tabular}

${ }^{\mathrm{z}}$ Data were collected at the end of both growing seasons in early October. ISGI and shoot quality values are the average of eight plants. Percent $\mathrm{N}$ and $\mathrm{C}: \mathrm{N}$ ratio values are the average of four measurements. For each measurement, four fully mature, current-season leaves were collected per plant then the leaves of two plants within a cultivar and treatment were combined to produce four replicates.

${ }^{\mathrm{y}}$ ISGI $=[$ (widest width increase + narrowest width increase $) / 2+$ height increase $] / 2$.

${ }^{\mathrm{x}}$ Shoot quality was rated on a 1 to 5 scale where $5=$ superior quality; $4=$ high quality; $3=$ marketable quality; 2 = low quality; and 1 = poor quality plant.

"Means within a column and cultivar followed by the same letter are not significantly different at the $P=$ 0.05 level using a protected Tukey's Studentized range test.

$\mathrm{C}: \mathrm{N}=$ carbon-to-nitrogen ratio.

Table 2. Effect of nitrogen rates on first (2008) and second (2009) growing season leaf color characteristics of lightness $\left(\mathrm{L}^{*}\right)$, hue angle $\left(\mathrm{h}^{\circ}\right)$, and chroma $\left(\mathrm{C}^{*}\right)$ and number of flower buds in Rhododendron 'Cunningham's White' and 'English Roseum'.

\begin{tabular}{|c|c|c|c|c|c|c|c|c|}
\hline \multirow{2}{*}{$\begin{array}{l}\text { Nitrogen rate } \\
\text { (mg N/container) }\end{array}$} & $\mathrm{L}^{* y}$ & $h^{\circ \mathrm{x}}$ & $\mathrm{C}^{* \mathrm{w}}$ & $\begin{array}{c}\text { Number of } \\
\text { flower buds } \\
\text { per plant }\end{array}$ & $\mathrm{L}^{*}$ & $h^{\circ}$ & $\mathrm{C}^{*}$ & $\begin{array}{c}\text { Number of } \\
\text { flower buds } \\
\text { per plant }\end{array}$ \\
\hline & \multicolumn{4}{|c|}{2008 growing season } & \multicolumn{4}{|c|}{2009 growing season } \\
\hline \multicolumn{9}{|c|}{ Cunningham's White } \\
\hline 150 & $34.4 \mathrm{a}^{\mathrm{v}}$ & $129.7 \mathrm{a}$ & $15.6 \mathrm{a}$ & $14.0 \mathrm{a}$ & $38.2 \mathrm{a}$ & $119.4 \mathrm{a}$ & $26.2 \mathrm{a}$ & $33.8 \mathrm{a}$ \\
\hline 75 & $38.8 \mathrm{~b}$ & $125.3 \mathrm{~b}$ & $24.0 \mathrm{~b}$ & $11.9 \mathrm{a}$ & $41.1 \mathrm{~b}$ & $120.5 \mathrm{a}$ & $26.6 \mathrm{a}$ & $18.5 \mathrm{~b}$ \\
\hline 25 & $53.6 \mathrm{c}$ & $110.6 \mathrm{c}$ & $46.3 \mathrm{c}$ & $12.6 \mathrm{a}$ & $49.1 \mathrm{c}$ & $112.1 \mathrm{~b}$ & $34.7 \mathrm{~b}$ & $6.6 \mathrm{c}$ \\
\hline \multicolumn{9}{|c|}{ English Roseum } \\
\hline 150 & $38.1 \mathrm{a}$ & $127.7 \mathrm{a}$ & $22.3 \mathrm{a}$ & $10.4 \mathrm{a}$ & $39.6 \mathrm{a}$ & $121.4 \mathrm{a}$ & $28.3 \mathrm{a}$ & $28.8 \mathrm{a}$ \\
\hline 75 & $42.7 \mathrm{~b}$ & $123.3 \mathrm{~b}$ & $30.9 \mathrm{~b}$ & $9.1 \mathrm{a}$ & $43.1 \mathrm{~b}$ & $119.4 \mathrm{a}$ & $31.0 \mathrm{ab}$ & $9.6 \mathrm{~b}$ \\
\hline 25 & $51.9 \mathrm{c}$ & $116.0 \mathrm{c}$ & $44.0 \mathrm{c}$ & $8.1 \mathrm{a}$ & $48.2 \mathrm{c}$ & $109.0 \mathrm{~b}$ & $35.1 \mathrm{~b}$ & $2.9 \mathrm{c}$ \\
\hline
\end{tabular}

${ }^{\mathrm{z}}$ Data were collected at the end of both growing seasons in early October. Values for $\mathrm{L}^{*}, \mathrm{~h}^{\circ}$, and $\mathrm{C}^{*}$ and number of flower buds represent the average of eight plants.

${ }^{\mathrm{y}} \mathrm{L} *$ is the color lightness or value $0=$ black to $100=$ white.

${ }^{\mathrm{x}} \mathrm{h}^{\circ}$ is the attribute of color perceived (red, yellow, green, blue, or intermediate between adjacent pairs arranged on a $360^{\circ}$ color wheel $\left(0^{\circ}=\right.$ red, $90^{\circ}=$ yellow, $180^{\circ}=$ green, and $270^{\circ}=$ blue $)$.

${ }^{\mathrm{w}} \mathrm{C}^{*}$ is the degree of color from gray (equal 0 ) to pure chromatic color.

${ }^{v}$ Means within a column and cultivar followed by the same letter are not significantly different at the $P=$ 0.05 level using a protected Tukey's Studentized range test.

$\mathrm{N}=$ nitrogen 
whereas 'Compact P.J.M.' quality was similar at the 150- and 75-mg N rates but lower at the 25-mg $\mathrm{N}$ rate. As $\mathrm{N}$ rate increased, the number of flower buds on 'Cunningham's White' and 'English Roseum' increased (Table 2) with five and nearly 10 times, respectively, the number of buds at the $150-\mathrm{mg}$ $\mathrm{N}$ rate as the $25-\mathrm{mg}$ rate after two growing seasons. Results of root growth ratings indicated $\mathrm{N}$ rate did not influence root growth of the rhododendron cultivars in either growing season (data not shown).

Increasing the $\mathrm{N}$ rate produced 'Cunningham's White' and 'English Roseum' plants with significantly darker (lower $\mathrm{L}^{*}$ ) and greener $\left(\right.$ greater $h^{\circ}$ ) leaves with a decreased color saturation (lower $\mathrm{C}^{*}$ ) after one growing season (Table 2). At the end of the second growing season, $\mathrm{L}^{*}$ values indicated leaf color again was darker with increasing $\mathrm{N}$ application (Table 2). Hue angle was similar, indicating greener leaves, at the 150- and $75-\mathrm{mg} \mathrm{N}$ rates for both cultivars, whereas leaves of plants fertilized at the $25-\mathrm{mg} \mathrm{N}$ rate were more yellow (lower hue ${ }^{\circ}$ ). Chroma of 'Cunningham's White' leaves at the 150- and $75-\mathrm{mg} \mathrm{N}$ rates was similar in 2009 but 'English Roseum' $\mathrm{C}^{*}$ at the 75 -mg N rate did not differ significantly from either the 150 - or the 25 -mg N rates (Table 2).

Leaf $\mathrm{N}$ concentration measured at the end of the first growing season increased as $\mathrm{N}$ rate increased for all three cultivars (Table 1). At the end of the second growing season, leaf $\mathrm{N}$ concentration response to $\mathrm{N}$ fertilizer treatment was also similar for all three cultivars and the trend was similar to the first season's results with $\mathrm{N}$ concentration increasing as $\mathrm{N}$ fertilizer rate increased. However, at the end of the second growing season, only the $150-\mathrm{mg} \mathrm{N}$ rate was significantly different from the 75 - and $25-\mathrm{mg}$ rates (Table 2 ).

Leaf C:N ratio was larger at the $25-\mathrm{mg}$ $\mathrm{N}$ and smaller at the $150-\mathrm{mg} \mathrm{N}$ rate for all three cultivars the first growing season (Table 1). For 'Cunningham's White' and 'English Roseum', the 75-mg N rate C:N ratios were greater than the $150-\mathrm{mg}$ rate but not for 'Compact P.J.M.'. The second growing season leaves of the 25 and $75 \mathrm{mg}$ N-fertilized 'Compact P.J.M.' and 'Cunningham's White' plants had greater C:N ratios than those fertilized with $150 \mathrm{mg}$ N. Results for 'English Roseum' were similar except $\mathrm{C}: \mathrm{N}$ ratio of the $75-\mathrm{mg}$ plants was not significantly different from either the 150- or 25-mg N rate.

Cultivar susceptibility to $\mathrm{P}$. ramorum. Infection frequency was greater on wounded leaves of 'Compact PJM' in both years than on unwounded leaves (Table 3), and there was no significant difference in infection frequency for wounded and unwounded treatments on the two susceptible cultivars $(P=$ 0.0011, 'Compact P.J.M.'; $P=0.7015$, 'Cunningham's White'; $P=0.0756$ 'English Roseum', $t$ test). Lesion area differed on wounded compared with unwounded leaves for each cultivar and $\mathrm{N}$ treatment in both years, but these differences were not always significant (Table 4).
There were significant differences among cultivars in susceptibility to $P$. ramorum, with 'Compact P.J.M.' being the most resistant, 'Cunningham's White' was intermediate, and 'English Roseum' the most susceptible based on infection frequency results (Table 3). Overall analysis of lesion size

after $10 \mathrm{~d}$ showed that there was a significant difference in the severity of $P$. ramorum infection on the three cultivars. Typically, 'Compact P.J.M.' had the smallest lesions, whereas 'English Roseum' had the largest (Table 4). Infection frequency and lesion size were the most variable on the cultivar

Table 3. Effect of nitrogen fertilizer application rates on susceptibility to Phytophthora ramorum (percent of samples with visible lesions) on leaves of Rhododendron 'Compact PJM', 'Cunningham's White', and 'English Roseum' sampled in early October during the first (2008) and second (2009) growing season.

\begin{tabular}{|c|c|c|c|c|}
\hline \multirow{2}{*}{$\begin{array}{l}\text { Nitrogen rate } \\
\text { (mg N/container) }\end{array}$} & \multicolumn{2}{|c|}{2008} & \multicolumn{2}{|c|}{2009} \\
\hline & Wounded ${ }^{\mathrm{z}}(\%)$ & Unwounded (\%) & Wounded (\%) & Unwounded (\%) \\
\hline & \multicolumn{4}{|c|}{ Compact P.J.M. } \\
\hline 150 & $17 \mathrm{a}^{\mathrm{y}}$ & $4 \mathrm{a} * \mathrm{x}$ & $50 \mathrm{a}$ & $0 \mathrm{a} *$ \\
\hline 75 & $46 \mathrm{ab}$ & $13 \mathrm{a} *$ & $42 \mathrm{a}$ & $0 \mathrm{a} *$ \\
\hline \multirow[t]{2}{*}{25} & $46 \mathrm{ab}$ & $13 \mathrm{a} *$ & $46 \mathrm{a}$ & $4 \mathrm{a}^{*}$ \\
\hline & \multicolumn{4}{|c|}{ Cunningham's White } \\
\hline 150 & $88 \mathrm{~b}$ & $83 \mathrm{~b}$ NS & $100 \mathrm{~b}$ & $96 \mathrm{~b}$ NS \\
\hline 75 & $100 \mathrm{c}$ & $83 \mathrm{~b}$ NS & $96 \mathrm{~b}$ & $83 \mathrm{~b}$ NS \\
\hline \multirow[t]{2}{*}{25} & $96 \mathrm{bc}$ & $79 \mathrm{~b}$ NS & $92 \mathrm{~b}$ & $83 \mathrm{~b}$ NS \\
\hline & \multicolumn{4}{|c|}{ English Roseum } \\
\hline 150 & $100 \mathrm{c}$ & $100 \mathrm{~b}$ NS & $100 \mathrm{~b}$ & $96 \mathrm{~b}$ NS \\
\hline 75 & $100 \mathrm{c}$ & $100 \mathrm{~b}$ NS & $100 \mathrm{~b}$ & $96 \mathrm{~b}$ NS \\
\hline 25 & $100 \mathrm{c}$ & $100 \mathrm{~b}$ NS & $100 \mathrm{~b}$ & $100 \mathrm{~b}$ NS \\
\hline
\end{tabular}

${ }^{\mathrm{z}}$ For wounding treatments an injury to the leaf surface was made with a pin after inoculation. Values represent the average of 24 leaves.

${ }^{\mathrm{y}}$ Means within a column across cultivars with different letters are significantly different at $P=0.05\left(\chi^{2}\right.$ test, Marascuilo procedure). There were no significant differences in infection frequency among $\mathrm{N}$ concentrations when cultivars were considered separately.

$\mathrm{x*}$ and NS indicate significance and non-significance of wounding treatment within a year, cultivar, and N rate treatment (Student's $t$ test, $P<0.05$ ).

$\mathrm{N}=$ nitrogen.

Table 4. Mean P. ramorum lesion area $\left(\mathrm{mm}^{2}\right)$ of symptomatic infected leaves on three Rhododendron cultivars grown under three nitrogen fertilizer application rates.

\begin{tabular}{|c|c|c|c|c|}
\hline \multirow{2}{*}{$\begin{array}{l}\text { Nitrogen rate } \\
\text { (mg N/container) }\end{array}$} & \multicolumn{2}{|c|}{2008} & \multicolumn{2}{|c|}{2009} \\
\hline & Wounded $^{\mathrm{z}}$ & Unwounded & Wounded & Unwounded \\
\hline & \multicolumn{4}{|c|}{ Compact P.J.M. } \\
\hline 150 & $\begin{array}{l}19.32 \mathrm{~b}^{\mathrm{y}} \\
\mathrm{n}=4^{\mathrm{w}}\end{array}$ & $\begin{array}{l}228.89^{x} \\
n=1\end{array}$ & $\begin{array}{l}44.20 \mathrm{a} \\
\mathrm{n}=12\end{array}$ & $\begin{array}{l}0.00 \\
n=0\end{array}$ \\
\hline 75 & $\begin{array}{c}110.04 a b \\
n=11\end{array}$ & $\begin{array}{c}10.69 \\
n=3\end{array}$ & $\begin{array}{l}20.12 \mathrm{a} \\
\mathrm{n}=10\end{array}$ & $\begin{array}{l}0.00 \\
n=0\end{array}$ \\
\hline \multirow[t]{2}{*}{25} & $\begin{array}{c}187.16 \mathrm{a} \\
\mathrm{n}=11\end{array}$ & $\begin{array}{l}46.02 \\
n=3\end{array}$ & $\begin{array}{l}51.39 \mathrm{a} \\
\mathrm{n}=11\end{array}$ & $\begin{array}{l}198.00 \\
n=1\end{array}$ \\
\hline & \multicolumn{4}{|c|}{ Cunningham's White } \\
\hline 150 & $\begin{array}{c}233.52 \mathrm{a} \\
\mathrm{n}=21\end{array}$ & $\begin{array}{c}200.25 \mathrm{a} \mathrm{NS}^{\mathrm{v}} \\
\mathrm{n}=20\end{array}$ & $\begin{array}{c}189.55 \mathrm{a} \\
\mathrm{n}=24\end{array}$ & $\begin{array}{c}181.60 \mathrm{a} \text { NS } \\
n=23\end{array}$ \\
\hline 75 & $\begin{array}{c}201.10 \mathrm{a} \\
\mathrm{n}=24\end{array}$ & $\begin{array}{c}217.31 \mathrm{a} * \\
\mathrm{n}=20\end{array}$ & $\begin{array}{c}112.29 b \\
n=23\end{array}$ & $\begin{array}{c}89.13 \mathrm{~b} \text { NS } \\
\mathrm{n}=20\end{array}$ \\
\hline \multirow[t]{2}{*}{25} & $\begin{array}{c}199.43 \mathrm{a} \\
\mathrm{n}=23\end{array}$ & $\begin{array}{c}176.32 \text { a NS } \\
n=19\end{array}$ & $\begin{array}{c}161.61 \mathrm{a} \\
\mathrm{n}=22\end{array}$ & $\begin{array}{c}102.28 \mathrm{~b} * \\
\mathrm{n}=20\end{array}$ \\
\hline & \multicolumn{4}{|c|}{ English Roseum } \\
\hline 150 & $\begin{array}{c}502.17 \mathrm{a} \\
\mathrm{n}=24\end{array}$ & $\begin{array}{c}659.69 \mathrm{a}^{*} \\
\mathrm{n}=24\end{array}$ & $\begin{array}{c}434.13 \mathrm{a} \\
\mathrm{n}=24\end{array}$ & $\begin{array}{c}408.30 \text { a NS } \\
n=23\end{array}$ \\
\hline 75 & $\begin{array}{c}396.04 a \\
n=24\end{array}$ & $\begin{array}{c}456.26 \mathrm{~b} * \\
\mathrm{n}=24\end{array}$ & $\begin{array}{c}311.52 b \\
n=24\end{array}$ & $\begin{array}{c}296.18 b \text { NS } \\
n=23\end{array}$ \\
\hline 25 & $\begin{array}{c}282.11 \mathrm{~b} \\
\mathrm{n}=24\end{array}$ & $\begin{array}{c}347.40 \mathrm{c}^{*} \\
\mathrm{n}=24\end{array}$ & $\begin{array}{c}280.88 b \\
n=24\end{array}$ & $\begin{array}{c}241.98 \mathrm{~b} \text { NS } \\
\mathrm{n}=24\end{array}$ \\
\hline
\end{tabular}

${ }^{\mathrm{z}}$ For wounding treatments, an injury to the leaf surface was made with a pin after inoculation.

${ }^{\mathrm{y}}$ Means within a column and within a cultivar with the same letter are not significantly different at $P=0.05$ (Kruskal-Wallis test, Dunn's procedure).

'As a result of low infection frequency, statistical tests were not done on unwounded 'Compact P.J.M.'. ${ }^{\mathrm{w}} \mathrm{n}=$ number of symptomatic infected leaves.

${ }^{\mathrm{N}} \mathrm{NS}$ and $*$ indicates non-significance and significance of wounding treatment within a year, cultivar, and $\mathrm{N}$ rate treatment (Student's $t$ test, $P<0.05$ ).

$\mathrm{N}=$ nitrogen. 
Compact P.J.M. The relationship of foliar $\mathrm{N}$ concentration and lesion area was the strongest in 'English Roseum' (Fig. 2A), where lesions developed on both wounded and unwounded inoculation sites and lesion size increased with increasing foliar $\mathrm{N}$ concentration $\left(R^{2}=0.9611, P=0.000574\right)$. Lesion area was greater on all cultivars in 2008 than in $2009\left(P=1.36 \times 10^{-10}, t\right.$ test $)$. On unwounded 'Compact P.J.M.', infection frequency was low with the number of lesions produced between $0 \%$ and $16 \%$.

Leaf $\mathrm{N}$ concentration and C:N ratio (Fig. 2) were strongly correlated with lesion area on wounded and unwounded leaves in both years for the cultivar English Roseum. A similar trend was seen for 'Cunningham's White'. No linear relationship was seen for these parameters in 'Compact PJM'.

\section{Discussion}

Nitrogen rates for this study were intended to produce a range in growth response, leaf $\mathrm{N}$ concentration, and $\mathrm{C}: \mathrm{N}$ ratio of three evergreen rhododendron cultivars with varying susceptibility to $P$. ramorum. At the end of both growing seasons, our results showed all three rhododendron cultivars growing in 11.4-L containers and receiving the low rate of $25 \mathrm{mg} \mathrm{N} /$ container twice weekly had smaller ISGI, lower visual quality rating, and the lowest leaf $\mathrm{N}$ concentration (Tables 1 and 2). At the high $\mathrm{N}$ rate of $150 \mathrm{mg} \mathrm{N} /$ container, the cultivars had larger ISGI, higher visual quality rating, and the highest leaf $\mathrm{N}$ concentration. Leaf $\mathrm{C}: \mathrm{N}$ ratio was typically the inverse of leaf $\mathrm{N}$ concentration with plants fertilized at the high $\mathrm{N}$ rate having the lowest leaf $\mathrm{C}: \mathrm{N}$ ratio and plants at the low $\mathrm{N}$ rate having the largest C:N ratio. Plants fertilized with the medium $\mathrm{N}$ rate $(75 \mathrm{mg} \mathrm{N} /$ container) were intermediate to the 150 - and $25-\mathrm{mg} \mathrm{N}$ plants for the measured variables; occasionally the 75-mg $\mathrm{N}$ rate differences were not statistically different from either the 150 - or the 25-mg N treatments, or both. The evergreen rhododendron 'Scintillation', grown in 3.8-L containers, exhibited significant linear and quadratic increases in shoot growth and leaf
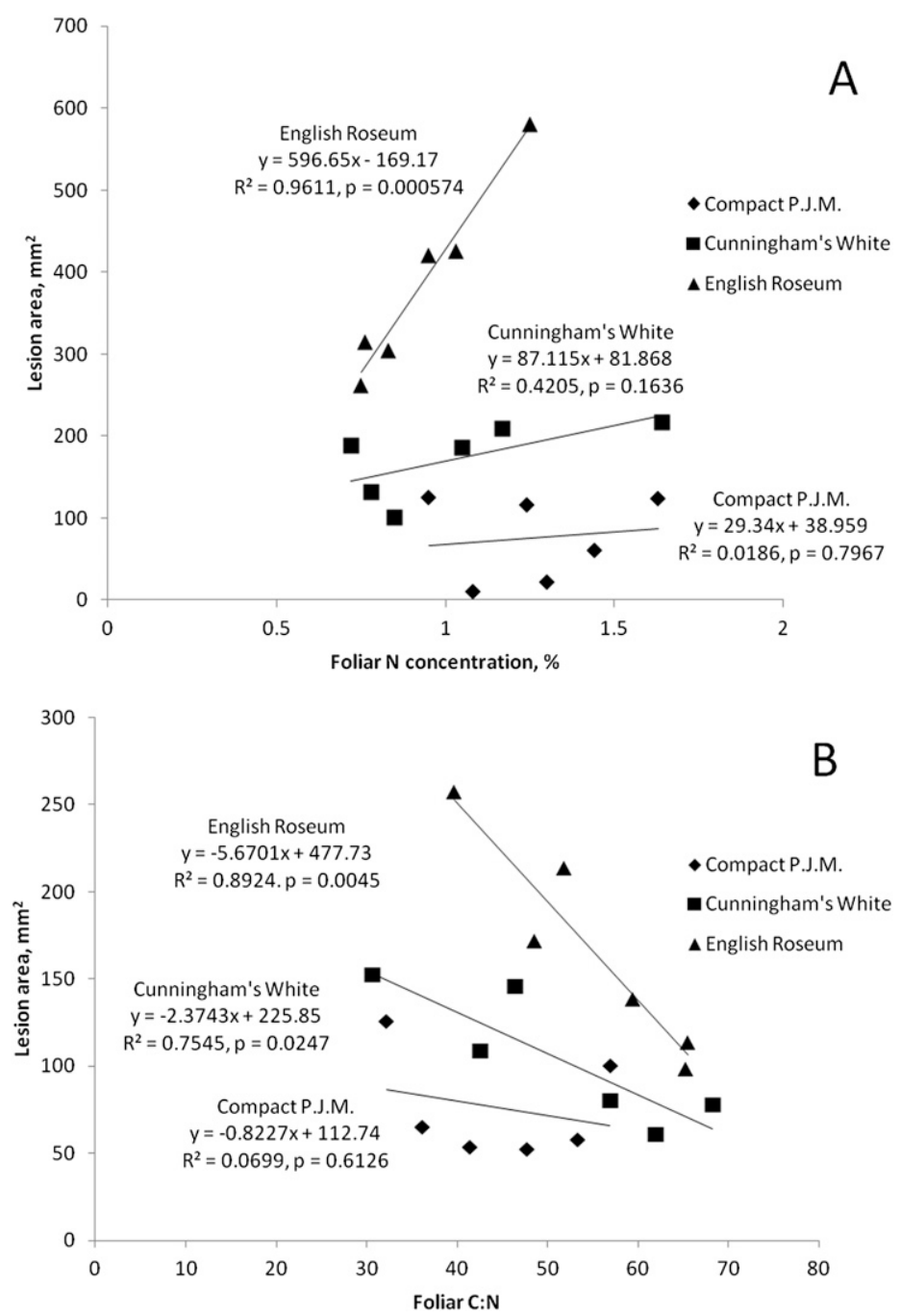

Fig. 2. Relationship of lesion area caused by Phytophthora ramorum to foliar nitrogen $(\mathrm{N})$ concentration (A) and to foliar carbon (C):N ratio (B) for three Rhododendron cultivars. Data points represent mean values for each cultivar and applied $\mathrm{N}$ rate for years 2008 and 2009 lesion area on combined wounded and unwounded foliage.

$\mathrm{N}$ concentration as $\mathrm{N}$ rate increased from 0 to $320 \mathrm{mg} \mathrm{N} /$ container in $80-\mathrm{mg}$ increments (Kuo et al., 1997). Bi et al. (2007) and Scagel et al. (2007) indicated that a $\mathrm{N}$ rate of $140 \mathrm{mg} \cdot \mathrm{L}^{-1}$ (35 mg N/container) was in excess of growth requirements for deciduous and evergreen rhododendron cultivars in 3.8-L containers and used this rate in their $\mathrm{N}$ nutrition studies.

Root growth of all three rhododendron cultivars was similar for both growing seasons. Roots grew to the bottom of the container and root growth at the periphery of the root ball was substantial but container substrate was readily visible. Nitrogen rates similar to those used in this experiment did not affect root growth ratings of Rhododendron 'Scintillation' (Kuo et al., 1997) or Kalmia latifolia 'Elf' (Hummel et al., 1990).

Leaf color of 'Cunningham's White' and 'English Roseum' was darker and more green as $\mathrm{N}$ application increased the first growing season (Table 2). Nitrogen effect on leaf color the second seaon was similar to the first. Rettke et al. (2006) used a Minolta chroma meter to show $\mathrm{N}$ applications to fieldgrown apricot trees resulted in darker and greener leaves. The Minolta chroma meter was found to provide a reliable indication of turfgrass leaf chlorophyll content and was considered to have the potential to guide $\mathrm{N}$ management (Mangiafico and Guillard, 2005).

The number of flower buds on 'Cunningham's White' and 'English Roseum' was not influenced by $\mathrm{N}$ rate the first growing season but the second growing season flower bud numbers increased significantly as $\mathrm{N}$ fertilizer rate increased (Table 2). Plants of 'Cunningham's White' grown at the 150-mg N rate had $80 \%$ and $45 \%$ more flower buds, respectively, than plants grown at the 25and 75-mg N rates. 'English Roseum' 150-mg $\mathrm{N}$ plants had $90 \%$ and $67 \%$ more buds than $25-$ and $75-\mathrm{mg} \mathrm{N}$ rate plants, respectively. Increased flower bud numbers are a typical response of young rhododendron cultivars to increased fertility (Myre and Mortensen, 1964; Witt, 1994). Plants with numerous flower buds are prized by consumers and thus more marketable than plants with fewer flower buds. The challenge for growers is to apply sufficient fertilizer to produce highquality, marketable plants while avoiding excessive fertilizer application and the attendant problems with environmental contamination and plant disease enhancement.

Excess $\mathrm{N}$ will stimulate some pathogens, and some diseases are stimulated or decreased by nitrogen in the form of either ammonium $\left(\mathrm{NH}_{4}+\right)$ or nitrate $\left(\mathrm{NO}_{3}{ }^{-}\right)$(Huber and Watson, 1974). In soil, increased $\mathrm{N}$ in the form of $\mathrm{NH}_{4}+$ or $\mathrm{NO}_{2}^{-}$has been shown to reduce germination of propagules of several root-infecting Phytophthora species (Tsao and Oster, 1981). High $\mathrm{N}$ rates increased susceptibility of potato to foliar infection by $P$. infestans, but resistance to the fungal pathogen Alternaria solani was increased (Mittelstrab et al., 2006). Opportunistic plant disease organisms that infect weak, slowly 
growing, or senescing plants may be more aggressive on plants that are deficient in $\mathrm{N}$ (Snoeijers et al., 2000).

In this study, lesion area on 'Compact P.J.M.', the most resistant cultivar, was higher at the lowest $\mathrm{N}$ rate on wounded leaves in 2008, although infection frequency was low on both wounded and unwounded material. It is difficult to draw conclusions based on lesion area from this cultivar because the results were variable and infection frequency was low. Lesion area of the moderately susceptible cultivar, Cunningham's White, was largest at the highest $\mathrm{N}$ rate but only for unwounded leaves in 2009. Consistent results were obtained from the susceptible cultivar, English Roseum. Lesion area increased with increasing foliar $\mathrm{N}$ concentration in 'English Roseum'. The results for currentseason mature foliage of 'English Roseum' in this study agree with those of Hoitink et al. (1986), who found that increasing $\mathrm{N}$ concentrations in juvenile foliage were positively correlated with $P$. cactorum lesion size on the cultivar Roseum Elegans. Both 'English Roseum' and 'Roseum Elegans' are hybrids of $R$. catawbiense. 'Cunningham's White' is a hybrid of $R$. ponticum and $R$. caucasicum. Infection by the EU1 lineage of $P$. ramorum on $R$. catawbiense, $R$. ponticum, and $R$. caucasicum is more severe than on $R$. carolinianum, one of the parents of 'Compact P.J.M.' (De Dobbelaere et al., 2009). These authors also found more severe infection on 'Roseum Elegans' than on 'Cunningham's White', although 'Compact P.J.M.' was not tested.

In a survey of 15 nurseries in Washington and Oregon (12 of which were producing field-grown plants and three of which were producing container-grown plants), foliar $\mathrm{N}$ concentrations in mature leaves collected from 'Roseum Elegans' plants in January were found to be $1.73 \%$ for plants rated of average quality and $1.9 \%$ for the most highly rated plants (Ticknor and Long, 1978). Although the amounts of foliar $\mathrm{N}$ detected in this study were less than those considered optimal in the 1970s nursery survey, all cultivars fertilized at the $75-$ and $150-\mathrm{mg}$ $\mathrm{N}$ rates were of marketable or superior quality. In Season 2, the number of flower buds averaged 34 and 29 per plant at the $150-\mathrm{mg}$ $\mathrm{N}$ rate for 'Cunningham's White' and 'English Roseum', respectively.

The environmental impact of $\mathrm{N}$ applications in nurseries has been the driving force behind research demonstrating that marketable container plants can be produced using less $\mathrm{N}$ and water. Results of this study, showing larger $P$. ramorum lesions at the highest $\mathrm{N}$ rate on leaves of the most susceptible cultivar, English Roseum, may add impetus for reduced $\mathrm{N}$ inputs and for additional research to determine optimal fertilization practices for nursery growers.

\section{Literature Cited}

APHIS. 2010. APHIS list of plants regulated and associated with Phytophthora ramorum.
27 Aug. 2010. <http://www.aphis.usda.gov/plant health/plant_pest_info/pram/downloads/pdf_ files/usdaprlist.pdf>.

APHIS. 2012. Phytophthora ramorum/sudden oak death program updates. 15 Sept. 2012. < http:// www.aphis.usda.gov/plant_health/plant_pest_ info/pram/updates.shtml $>$.

Bi, G., C.F. Scagel, L.H. Fuchigami, and R.P. Regan. 2007. Differences in growth, nitrogen uptake and storage between two containergrown cultivars of rhododendron. J. Environ. Hort. 25:13-20.

Biernbaum, J.A. 1992. Root-zone management of greenhouse container-grown crops to control water and fertilizer use. HortTechnology 2:127132 .

Cabrera, R.I. 2003. Nitrogen balance for two container-grown woody ornamental plants. Sci. Hort. 97:297-308.

Chen, J., Y. Huang, and R.D. Caldwell. 2001. Best management practices for minimizing nitrate leaching from container-grown nurseries. In: Optimizing nitrogen management in food and energy production and environmental protection: Proceedings of the 2nd International Nitrogen Conference on Science and Policy. TheScientificWorld 1(suppl 2):96-102.

Dart, N.L. and G.A. Chastagner. 2007a. High recovery rate of Phytophthora from containerized nursery stock pots at a retail nursery highlights potential for spreading exotic oomycetes. Online. Plant Health Prog. DOI: 10.1094/ PHP-2007-0816-01-BR.

Dart, N.L. and G.A. Chastagner. 2007b. Estimated economic losses associated with the destruction of plants due to Phytophthora ramorum quarantine efforts in Washington State. Online. Plant Health Prog. DOI: 10.1094/PHP-20070508-02-RS.

De Dobbelaere, I., A. Vercauteren, N. Speybroeck, D. Berkvens, E. Van Bockstaele, M. Maes, and K. Huengens. 2009. Effect of host factors on the susceptibility of Rhododendron to Phytophthora ramorum. Plant Pathol. 59:301-312.

Frankel, S.J. 2008. Sudden oak death and Phytophthora ramorum in the USA: A management challenge. Australas. Plant Pathol. 37:19-25.

Halsall, D.M., R.I. Forrester, and T.E. Moss. 1983. Effects of nitrogen, phosphorus and calcium nutrition on growth of eucalypt seedlings and on the expression of disease associated with Phytophthora cinnamomi infection. Aust. J. Bot. 31:341-355.

Hansen, E.M., J.L. Parke, and W. Sutton. 2005a Susceptibility of Oregon forest trees and shrubs to Phytophthora ramorum: A comparison of artificial inoculation and natural infection. Plant Dis. 89:63-70.

Hansen, E., W. Sutton, J. Parke, and R. Linderman. 2005b. Phytophthora ramorum and Oregon forest trees - one pathogen, three diseases. Sudden oak death science symposium, Monterey, CA, 15-18 Dec. 2002. 18 Oct. 2011. <http://danr.ucop.edu/ ihrmp/sodsymp/poster/poster07.html $>$.

Hoitink, H.A.J., M.E. Watson, and W.R. Faber. 1986. Effect of nitrogen concentration in juvenile foliage of Rhododendron on Phytophthora dieback severity. Plant Dis. 70:292-294.

Huber, D.M. and R.D. Watson. 1974. Nitrogen form and plant disease. Annu. Rev. Phytopathol. 12:139-165.

Hummel, R.L., C.R. Johnson, and O.M. Lindstrom. 1990. Root and shoot growth response of three container-grown Kalmia latifolia L. cultivars at two locations to growing medium and nitrogen form. J. Environ. Hort. 8:10-13.

Krucker, M., R.L. Hummel, and C. Cogger. 2010. Chrysanthemum production in composted and noncomposted organic waste substrates fertilized with nitrogen at two rates using surface and subirrigation. HortScience 45:1695-1701.

$\mathrm{Ku}$, C.S.M. and D.R. Hershey. 1997. Growth response, nutrient leaching and mass balance for potted pointsettia. I. Nitrogen. J. Amer. Soc. Hort. Sci. 122:452-458.

Kuo, S., R.L. Hummel, E.J. Jellum, and D.W. Privett. 1997. Fishwaste compost effects on Rhododendron growth and nitrogen leaching and transformation. J. Environ. Qual. 26:733739.

Lea-Cox, J.D., D.S. Ross, and K.M. Teffeau. 2004. Developing water and nutrient management plans for container nursery and greenhouse production systems. Acta Hort. 633:373-379.

Majsztrik, J.C., A.G. Ristvey, and J.D. Lea-Cox. 2011. Water and nutrient management in the production of container-grown ornamentals. Hort. Rev. 38:253-297.

Mangiafico, S.S. and K. Guillard. 2005. Turfgrass reflectance measurements, chlorophyll, and soil nitrated desorbed from anion exchange membranes. Crop Sci. 45:259-265.

McGuire, R.G. 1992. Reporting of objective color measurements. HortScience 27:1254-1255.

Mittelstrab, K., D. Treutter, M. Plebl, W. Heller, E.F. Elstner, and I. Heiser. 2006. Modification of primary and secondary metabolism of potato plants by nitrogen application differentially affects resistance to Phytophthora infestans and Alternaria solani. Plant Biol. 8:653-661.

Myre, A.S. and W.P. Mortensen. 1964. The effect of phosphorus on rhododendron flower-bud formation. Amer. Rhododendron Soc. Quar. Bul. 18:66-71

R Development Core Team. (2011). R: A language and environment for statistical computing. $\mathrm{R}$ Foundation for Statistical Computing, Vienna, Austria. 15 Feb. 2013. <http://www.R-project. org/ $>$.

Rettke, M.A., T.R. Pitt, N.A. Maier, and J.A. Jones 2006. Growth and yield responses of apricot (cv. Moorpark) to soil-applied nitrogen. Aust. J. Exp. Agr. 46:115-122.

Riedel, M., S. Werres, E. Elliott, K. McKeever, and S.F. Shamoun. 2012. Histopathological investigations of the infection process and propagule development of Phytophthora ramorum on rhododendron leaves. Online. Forest Phytophthoras 2. DOI: $10.5399 / \mathrm{osu} / \mathrm{fp} \cdot 2.1 .3036$.

Ristvey, A.G., J.D. Lea-Cox, and D.S. Ross. 2007. Nitrogen and phosphorus uptake efficiency and partitioning of container-grown azalea during spring growth. J. Amer. Soc. Hort. Sci. 132:563571.

Scagel, C.F., G. Bi, L.H. Fuchigami, and R.P. Regan. 2007. Seasonal variation in growth, nitrogen uptake and allocation by containergrown evergreen and deciduous rhododendron cultivars. HortScience 42:1440-1449.

Scagel, C.F., G. Bi, L.H. Fuchigami, and R.P. Regan. 2011. Effects of irrigation frequency and nitrogen fertilizer rate on water stress, nitrogen uptake, and plant growth of containergrown rhododendron. HortScience 46:15981603.

Snoeijers, S.S., A. Perez-Garcia, M.H.A.J. Joosten, and P.J.G.M. De Wit. 2000. The effect of nitrogen on disease development and gene expression in bacterial and fungal plant pathogens. Eur. J. Plant Pathol. 106:493-506.

Ticknor, R.L. and J.L. Long. 1978. Mineral content of rhododendron foliage. American Rhododendron Society Quarterly Bulletin 32:150-158.

Tjosvold, S.A., S.T. Koike, J.M. Davidson, and D.M. Rizzo. 2002. Susceptibility of azalea (Rhododendron) to Phytophthora ramorum. 
Sudden Oak Death Symposium, Monterey, CA. 18 Oct. 2011. <http://danr.ucop.edu/ihrmp/ sodsymp/poster/poster45.html>.

Tooley, P.W., K.L. Kyde, and L. Englander. 2004. Susceptibility of selected Ericaceous ornamental host species to Phytophthora ramorum. Plant Dis. 88:993-999.

Tsao, P.H. and J.J. Oster. 1981. Relation of ammonia and nitrous acid to suppression of Phytophthora in soils amended with nitrogenous organic substances. Phytopathology 71:53-59.
Vercauteren, A., M. Reidel, M. Maes, S. Werres, and K. Heungens. 2013. Survival of Phytophthora ramorum in Rhododendron root balls and rootless substrates. Plant Pathol. 62:166-176.

Werres, S., R. Marwitz, W.A. Man in't Veld, A.W.A.M. De Cock, P.J.M. Bonants, M 2001. Phytophthora ramorum sp nov., a new pathogen on rhododendron and viburnum. Mycological Res. 105:1155-1165.

Witt, H.H. 1994. Regulation of nitrogen supply of Rhododendron Hybrids. Acta Hort. 364:79-87.
Yeager, T.H., T.E. Bilderback, D. Fare, C. Gilliam, J.D. Lea-Cox, A.X. Niemiera, J.M. Ruter, K. Tilt, S. Warren, T. Whitwell, and R.D. Wright. 2007. Best managements practices: Guide for protecting nursery crops. 2nd Ed. Southern Nursery Association, Atlanta, GA.

Zwick, R. and L.A. Marascuilo. 1984. Selection of pairwise multiple comparison procedures for parametric and nonparametric analysis of variance models. Psychol. Bull. 95:148-155. 